\title{
START-UP AND PERFORMANCE OF UASB REACTORS USING ZEOLITE FOR IMPROVEMENT OF NITRATE REMOVAL PROCESS
}

\author{
S. Montalvo ${ }^{a}$, L. Guerrero ${ }^{b}$, M. Robles ${ }^{a}$, C. Mery ${ }^{b}$, C. Huiliñir ${ }^{a}$, R. Borja ${ }^{c} *$
}

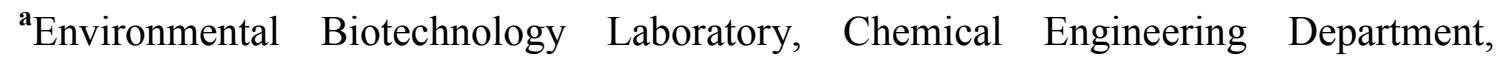
University of Santiago de Chile, Santiago de Chile, Chile.

${ }^{\mathbf{b}}$ Chemical and Environmental Department, Federico Santa María Technical University, Valparaíso, Chile.

${ }^{c}$ Instituto de la Grasa (CSIC), Avda. Padre Garcia Tejero, 4, 41012-Sevilla, Spain.

*Corresponding author at Instituto de la Grasa (CSIC), Avda. Padre Garcia Tejero, 4, 41012-Sevilla, Spain. Tel.: +34 954692516 (Ext. 152); fax: +34 95 4691262; E-mail address: rborja@cica.es (R. Borja).

\begin{abstract}
A first study on the use of Chilean natural zeolite of different particle sizes $(0.5,1$ and 2 $\mathrm{mm}$ in diameter) in laboratory-scale batch denitrificant reactors was carried out with the aim of assessing the microbial communities adhered to this material. Molecular techniques such as fluorescence in situ hybridization (FISH) and denaturing gradient gel electrophoresis (DGGE) fingerprints revealed a high microbial diversity with a strong presence of Gammaproteobacteria (70\% of the total microorganisms) in reactors with zeolite $0.5 \mathrm{~mm}$ in diameter. Archaea were only detected in the reactors with zeolite 1 $\mathrm{mm}$ in diameter. In addition, the acclimatization and start-up of two UASB reactors
\end{abstract}


(one without zeolite and the other with added zeolite $1 \mathrm{~mm}$ in diameter) were conducted following three consecutive and progressive stages using upward velocities from 0.10 to $0.44 \mathrm{~m} / \mathrm{h}$ in order to establish an experimental protocol suitable for the start-up of this type of reactors. Total $(100 \%)$ nitrate reduction was achieved in the UASB reactors with and without zeolite on the $7^{\text {th }}$ and $11^{\text {th }}$ days, respectively, of the second stage of the start-up period, showing the suitability of the use of this material in this type of reactors. Finally, a third study carried out with both UASB reactors operating in continuous mode at a high organic loading rate $\left(44 \mathrm{~kg} \mathrm{COD} / \mathrm{m}^{3} \cdot \mathrm{d}\right)$ and a very low HRT $(2.5 \mathrm{~h})$ revealed that the reactor with zeolite achieved a nitrate removal efficiency of $92.4 \%$ at a nitrogen load of $6.42 \mathrm{~kg} \mathrm{NO}_{3}^{-} /\left(\mathrm{m}^{3} \cdot \mathrm{d}\right)$. This last study also demonstrated the robustness of the UASB reactor with zeolite under nitrate load variations.

Keywords: denitrification, microbial communities, UASB reactors, start-up, zeolite.

\section{INTRODUCTION}

A continuous increase in the concentration of nitrate has been observed in groundwater reserves and surface waters (rivers, lakes, etc.) due to intensified agriculture, industrialization and urbanization (Benyoucef et al., 2013). To be specific, wastewaters with nitrogen compounds (nitrate, nitrite, ammonia, etc.) are generated by domestic services as well as many industries such as fertilizers, fisheries, metal finishing, agrofoods, slaughterhouses, etc. (Huiliñir et al., 2011; Cheikh et al., 2013). For instance, between $30 \%-70 \%$ of nitrogen fertilizers used in agriculture is lost into the environment and found in nitrate form in surface waters and ground waters, and used as drinking 
water in some countries (Cheikh et al., 2013). At high concentrations, nitrate consumption causes methemoglobinemia in infants. Likewise, nitrate is reduced to nitrite in the intestine and is known to be linked to several cancers. Moreover, nitrosamines are carcinogenic compounds that can be formed from nitrite in the stomach (Cheikh et al., 2013). In addition, ammonia and increased reactive nitrogen discharged into aquatic environments can cause serious oxygen depletion in those environments and, in general, nitrogen compounds can cause eutrophication of lakes and rivers (Benyoucef et al., 2013).

There are physicochemical and biological methods for removing the nitrogen present in wastewaters (Zhang et al., 2009; Andalib et al., 2012; Malekian et al., 2011; Montalvo et al., 2011; Rezakazemi et al., 2012; Bravo et al., 2013; Jiang et al., 2013; $\mathrm{Yu}$ et al., 2013). Physicochemical methods do not completely solve the problem because they transfer the pollutants from one matrix to another and are not cost effective. By contrast, biological processes remove the pollutants and, operating under adequate conditions, their final products are innocuous for the environment and byproducts can even be obtained for use as fertilizers (Yetilmezsoy and Sapci-Zengin, 2009; Uysal et al., 2010). Therefore, among various nitrogen removal methods, nitrification-denitrification processes are the most frequently used from a practical point of view and seem to be the most promising (Morita et al., 2008; Rodríguez at al., 2011).

The nitrification-denitrification process is carried out in two steps. During the first step, ammonia is aerobically converted into nitrate through nitrite, and in the second anoxic step nitrate is reduced to nitrite, nitric oxid, nitrous oxide and nitrogen gas by heterotrophic bacteria, with organic materials usually used as the electron donor for this 
reduction process. Finally, gaseous nitrogen $\left(\mathrm{N}_{2}\right)$ which escapes into the air causing no secondary contaminant effects is formed (Shen et al., 2013):

$$
\mathrm{NO}_{3}{ }^{-} \rightarrow \mathrm{NO}_{2}{ }^{-} \rightarrow \mathrm{NO}(\mathrm{g}) \rightarrow \mathrm{N}_{2} \mathrm{O}(\mathrm{g}) \rightarrow \mathrm{N}_{2}(\mathrm{~g})
$$

When using methanol as an extra carbon source while treating water with a low $\mathrm{C} / \mathrm{N}$ ratio, the overall denitrification reaction can be expressed as follows:

$$
6 \mathrm{NO}_{3}{ }^{-}+5 \mathrm{CH}_{3} \mathrm{OH} \rightarrow 5 \mathrm{CO}_{2}+3 \mathrm{~N}_{2}+7 \mathrm{H}_{2} \mathrm{O}+6 \mathrm{OH}^{-}
$$

The following reaction represents a typical reaction for synthesis or generation of microorganisms:

$$
3 \mathrm{NO}_{3}{ }^{-}+14 \mathrm{CH}_{3} \mathrm{OH}+\mathrm{CO}_{2}+3 \mathrm{H}^{+} \rightarrow 3 \mathrm{C}_{5} \mathrm{H}_{7} \mathrm{O}_{2} \mathrm{~N}+19 \mathrm{H}_{2} \mathrm{O}
$$

In practical terms, between $25 \%$ and $30 \%$ of the methanol needed as energy is used to generate microorganisms. From a laboratory test, the following equation has been developed to describe the global reaction of nitrate removal (Shen et al., 2013):

$$
\mathrm{NO}_{3}{ }^{-}+1.08 \mathrm{CH}_{3} \mathrm{OH}+\mathrm{H}^{+} \rightarrow 0.065 \mathrm{C}_{5} \mathrm{H}_{7} \mathrm{O}_{2} \mathrm{~N}+0.47 \mathrm{~N}_{2}+0.76 \mathrm{CO}_{2}+2.44 \mathrm{H}_{2} \mathrm{O}
$$

The use of efficient biological reactors such as the upflow anaerobic sludge blanket (UASB) for organic matter degradation has been widely assessed and checked, leading to high COD removal efficiencies operating with low hydraulic retention times (HRTs) (Puyol et al., 2009; Basu and Gupta, 2010). The UASB reactor involves the anaerobic degradation of organic wastes using a biomass which is not attached to a support medium but which aggregates under favourable conditions to produce particles with good settlement characteristics. These particles are known as granules and their formation, commonly termed "granulation", greatly enhances the efficiency of the process, producing high biomass retention times and enabling high organic loading rates to be achieved (Hulshoff Pol et al., 2004; Chong et al., 2012). 
One problem or disadvantage of the anaerobic process is its slow start-up phase. With the aim of accelerating the start-up of the UASB reactor, different methods have been tested, among them the addition of certain materials that could help granule formation. The use of zeolite is an alternative that may be evaluated to promote granule formation taking into account the favourable influence of this material in other biological purification processes (Fernandez et al., 2007; Mery et al., 2012; Montalvo et al., 2012). On the other hand, an in-depth analysis of the microbial communities developing during organic matter decomposition in anaerobic reactors could represent an important step in better understanding and monitoring the performance of the process. Understanding the involvement of specific microorganisms would be useful for controlling performance and maximum substrate decomposition during the anaerobic degradation of wastewaters (Rincon et al., 2008).

In this light, the aim of this work was to study the use of natural zeolite (a mineral composed basically of alumina-silicates) to help to increase the anaerobic biomass in UASB reactors, assessing the performance of these reactors in removing nitrates in denitrification processes when operating with synthetic wastewater. The start-up period of the modified UASB reactors was closely evaluated in order to develop an adequate starting experimental procedure. Previously, the identification of the microbial communities adhered to zeolite was also carried out in denitrification experiments performed in batch mode.

\section{MATERIALS AND METHODS}


Two different experimental runs were carried out throughout this study. Firstly, a set of batch experiments was performed in small laboratory-scale reactors with the aim of assessing the microbial communities adhered to natural zeolites with different particle sizes. Molecular techniques such as fluorescence in situ hybridization (FISH) and denaturing gradient gel electrophoresis (DGGE) fingerprints were used to evaluate the microbial profiles. A second run of experiments was conducted in laboratory-scale UASB reactors with and without zeolite with the aim of setting up an appropriate experimental protocol for the start-up of this type of reactors, which were operated in continuous mode.

\subsection{Batch denitrification experiments}

A first run of experiments was carried out for the identification of the microbial populations adhered to natural zeolite in batch denitrification processes. These experiments were performed in small-scale batch reactors with an operating volume of $0.25 \mathrm{~L}$ working at a temperature of $37^{\circ} \mathrm{C}$. Zeolite particle sizes $0.5 \mathrm{~mm}, 1 \mathrm{~mm}$ and 2 $\mathrm{mm}$ in diameter were used in this group of experiments. The operating conditions of the reactors are shown in Table 1. The inocula used in this set of assays were derived from an anaerobic sludge digester reactor which treats urban wastewaters.

Samples of biomass adhered to zeolite were taken from the reactors at the beginning and end of the experiment (28 days). In order to separate the biomass from the zeolite, these samples were subjected to ultrasound for 30 seconds using the Branson Sonifier 150 ultrasound equipment with 40\% amplitude. Subsequently, and with a view to analyzing the different microbial populations, samples were prepared using the molecular technique of fluorescence in situ hybridization (FISH) according to 
the protocol described by Amann et al. (1990). Table 2 shows the sequences, target organisms and percentage of formamide used in each case. To be specific, samples were fixed in 4\% paraformaldehyde, washed in phosphate buffer saline (PBS) and preserved in PBS-ethanol at $-20^{\circ} \mathrm{C}$ until used. For the hybridization procedure, the samples were fixed on a multi-dish slide at $46^{\circ} \mathrm{C}$ for 20 minutes and dried in ethanol. All the probes carried out are summarized and specified in Table 2. DAPI staining (4', 6-diamidino-2phenilindol) was used to corroborate that the observed fluorescence with the FISH technique corresponded to bacteria cells in order to quantify the existing microorganisms.

\subsection{Characteristics of the zeolite}

The Chilean natural zeolite used was obtained from the company Minera Formas $\left(\right.$ ZeoClean $\left.^{R}\right)$. Its main chemical composition was: $\mathrm{SiO}_{2}, 67.00 \% ; \mathrm{Al}_{2} \mathrm{O}_{3}, 13.01 \% ; \mathrm{Fe}_{2} \mathrm{O}_{3}$, $3.60 \% ; \mathrm{CaO}, 3.46 \% ; \mathrm{Na}_{2} \mathrm{O}, 1.32 \% ; \mathrm{TiO}_{2}, 0.28 \% ; \mathrm{MgO}, 0.78 \% ; \mathrm{K}_{2} \mathrm{O}, 0.53 \%$. In addition, the mineralogical composition of the zeolite used in all assays was: Clinoptilolite, 35\%; Mordenite, 15\%; Montmorillonite, 30\%; others (calcite, feldespate and quartz), $20 \%$.

\subsection{Characteristics of the inoculum}

The anaerobic inoculum used in all experiments was obtained from a full-scale anaerobic digester installed at the Urban Wastewater Treatment Plant (UWTP) La Farfana, located in Santiago de Chile. The main characteristics of the inoculum were: volatile suspended solids (VSS), $14.9 \mathrm{~g} / \mathrm{L}$; percentage of VSS (dry basis), 65.5; 
alkalinity (as $\mathrm{CaCO}_{3}$ ), $3930 \mathrm{mg} / \mathrm{L}$; volatile fatty acids (VFA, as acetic acid), $380 \mathrm{mg} / \mathrm{L}$; $\mathrm{pH}, 7.2$.

\subsection{Start-up and operational conditions of the laboratory-scale UASB reactors}

The second experimental run was carried out in two identical laboratory-scale UASB reactors, one operating with zeolite and the other without. The size and main characteristics of the UASB reactors were: length, $110 \mathrm{~cm}$; internal diameter, $10.5 \mathrm{~cm}$; thickness, $0.5 \mathrm{~cm}$; surface, $86.6 \mathrm{~cm}^{2}$; total volume, $9525 \mathrm{~cm}^{3}$.

The composition of the synthetic wastewater used for feeding the UASB reactors was: methanol, $3.17 \mathrm{~g} / \mathrm{L} ; \mathrm{NaNO}_{3}, 2.3 \mathrm{~g} / \mathrm{L}$; yeast extract, $0.1 \mathrm{~g} / \mathrm{L}$; peptone, $0.25 \mathrm{~g} / \mathrm{L}$; $\mathrm{K}_{2} \mathrm{HPO}_{4}, 238 \mathrm{mg} / \mathrm{L} ; \mathrm{KH}_{2} \mathrm{PO}_{4}, 183 \mathrm{mg} / \mathrm{L} ; \mathrm{NaHCO}_{3}, 4 \mathrm{~g} / \mathrm{L}$.

The start-up of the UASB reactors was carried out in 4 steps as follows:

1) Pre-acclimation step: initially $750 \mathrm{~mL}$ of anaerobic inoculum and 3 litres of synthetic wastewater were added to a UASB reactor, keeping this reactor at room temperature $\left(18^{\circ} \mathrm{C}-20^{\circ} \mathrm{C}\right)$. The reactor operated in this way without feeding for one week.

2) Stage 1: after a pre-acclimation period of one week, $1750 \mathrm{~mL}$ of mixed liquor from one UASB reactor were added to the second UASB reactor, leaving the same volume of mixed liquor $(1750 \mathrm{~mL})$ in the first reactor. The remaining 250 $\mathrm{mL}$ were removed from the first reactor and subsequently used for chemical analysis. Both reactors operated in batch mode with total recirculation at an upward velocity of $0.1 \mathrm{~m} / \mathrm{h}$ during the first day and $0.44 \mathrm{~m} / \mathrm{h}$ during the second one. This stage lasted only 2 days. 
3) Stage 2: upon completion of the first stage, $25 \mathrm{~g}$ of VSS were left in each reactor and $250 \mathrm{~g}$ zeolite were added to reactor 2 (at a ratio of $0.1 \mathrm{~g} \mathrm{VSS} / \mathrm{g}$ zeolite), while reactor 1 was operated without any added zeolite. Previous research works (Montalvo et al. 2005 and 2012) showed that anaerobic processes were favoured by the addition of natural zeolite at doses of between 0.05 and $0.3 \mathrm{~g}$ $\mathrm{VSS} / \mathrm{g}$ zeolite, the optimum value being 0.1. Moreover, the increase of the zeolite doses may affect the mass transfer of organic matter, either nutrients and metabolites, in the vicinity of zeolite particles and the microorganisms associated. In addition, high amounts of zeolite may be toxic due to the accumulation of heavy metals (Montalvo et al., 2005). Both reactors operated in batch mode with total recirculation with an upward velocity of $0.1 \mathrm{~m} / \mathrm{h}$ for 15 days.

4) Stage 3: both reactors (reactor 1 without zeolite and reactor 2 with added zeolite) were also operated in batch mode with total recirculation with an upward velocity of $0.44 \mathrm{~m} / \mathrm{h}$ for 7 days.

\subsection{Chemical analyses}

Chemical oxygen demand (COD) and volatile suspended solids were analysed according to the closed digestion and colorimetric 5220D and 2540B methods, respectively, of the Standard Methods for the Examination of Waters and Wastewaters (APHA, 1998). $\mathrm{pH}$ was determined using a $\mathrm{pH}$-meter model Crison 20 Basic. Nitrate and ammonium nitrogen were determined by selective electrodes. 


\section{RESULTS AND DISCUSSION}

\subsection{Identification of the microbial populations adhered to natural zeolite in the batch denitrification process}

For the correct analysis of denitrifying reactors due to high microbial growth the samples had to be diluted. The dilution was carried out in Ethanol and PBS at a ratio of 1:1.5:1.5. Denitrifying reactors showed Gammaproteobacteria communities with ratios inversely proportional to the size of the zeolite, i.e. the highest percentage was found for the smallest diameter of $0.5 \mathrm{~mm}$, for which $70 \%$ of these microorganisms was found, while for $1 \mathrm{~mm}$ and $2 \mathrm{~mm}$ diameters, the percentage of Gammaproteobacteria found was $40 \%$ and $30 \%$, respectively. These bacteria were found in grouped form exclusively for the $0.5 \mathrm{~mm}$ diameter. For the other diameters they were dispersed within a dispersed total biomass. Within this bacterial class the presence of Competibacter phosphatis was identified in denitrifying reactors with a zeolite diameter of $0.5 \mathrm{~mm}$ and $2 \mathrm{~mm}$ with percentages close to $30 \%$. Gammaproteobacteria include Pseudomonas, some of which use nitrate as an electron acceptor, and, therefore, play a key role in denitrification systems. Recent studies related to marine sediments (Mills et al., 2008) show a high abundance of Gammaproteobacteria in processes of nitrification and denitrification, attributable to a high level of metabolism of these microorganisms, which leads to rapid changes in oxygen and substrates as occurs in the sands of the sea. Figure 1 shows the images of FISH obtained for the reactors with zeolite diameters of 1.0 and $0.5 \mathrm{~mm}$. As can be seen, a strong presence of Gammaproteobacteria was observed in the reactors with zeolite $0.5 \mathrm{~mm}$ in diameter. 
Recent studies related to the biodegradation of PHAs under anoxic and anaerobic denitrifying batch conditions also revealed, based on $16 \mathrm{~S}$ rDNA analysis, that the denitrifying enriched culture was mainly composed of Gammaproteobacteria (19 clones out of a total of 23 clones) (Lu et al., 2011), similar to what is observed in our study.

Denitrification is an anaerobic process carried out by distinct phylogenetic microorganic groups of bacteria and archaea (Cheneby et al., 2000), where archaea may have been involved in nitrogen removal. Only in the reactors with zeolite $1 \mathrm{~mm}$ in diameter, cells not belonging to Eubacteria were identified. For this reason, these reactors were analysed for the presence of archaea, finding an $80 \%$ presence (Figure 1). Within archaea, the presence of Methanosaetaceae, Methanosarcina and Methanobacteria was analysed because of the high organic content of the culture medium, finding no presence of these archaea groups. However, the non-presence of Methanosarcina is not categorical, since this was analysed with fluorochrome fluos. Previous works have clearly demonstrated that the total number of bacteria can be measured by DAPI while bacterial community structures were estimated with FISH using oligonucleotide probes specific to ribosomal RNA of the domain bacteria and the domain archaea (Abe et al., 2003).

Archaeal phylotypes very closely related to members of the orders Methanosarcinales and Methanomicrobiales were found in two production waters of a low-temperature and low-salinity petroleum reservoir in Canada, which were examined using cultural and molecular approaches (Grabowski et al., 2005). The authors found significant amounts of denitrifers in these reservoirs and the dominant members of the 
culturable population were affiliated with the Firmicutes, the Deltaproteobacteria, the Epsilonproteobacteria, the Spirochaetes and the Euryarchaeota.

Since a greater microbial diversity in the samples of the anaerobic reactors whose diameter of zeolite was $1 \mathrm{~mm}$ was detected after applying the FISH technique, it was decided that a denaturing gradient gel electrophoresis (DGGE) analysis of bacteria from these reactors should be carried out by analysing samples of start-up (DNB 1) as well as samples of the end of the experiment (DNB 3). DGGE results show a pattern of bands of different intensity in different positions of the gel (Figure 2). In the course of the experiment, six communities of the phylum Firmicutes were developed, of which three were $99 \%$ similar to the genus Clostridium, which is considered a potential key player in denitrification processes.

The bacterial diversity in a sequencing batch biofilm reactor (SBBR) treating landfill leachate was also studied with a view to explaining the mechanism of nitrogen removal (Xiao et al., 2009). DGGE fingerprints based on total community 16S rRNA genes were analyzed with statistical methods, and excised DNA bands were sequenced. As in the present work, the results of phylogenetic analyses carried out by Xiao at al. (2009) also revealed high diversity within the SBBR biofilm community, and DGGE banding patterns showed that the community structure in the biofilm remained stable during the running period, observing also a dominant presence of the same microorganism groups than those detected in the present work. In the same way, denitrification processes in fixed bed reactors were simulated at laboratory-scale using anaerobic batch tests with immature compost (Trois et al., 2010a). This research showed that the original composition, nature, the carbon-to-nitrogen ratio $(\mathrm{C} / \mathrm{N})$ and the degree 
of maturity and stability of the substrates clearly play a key role in the denitrification process, impacting directly on the development of the bacterial population and, therefore, on the long-term removal efficiency. Therefore, the above-mentioned factors clearly influence on the denitrification process being very important for an appropriate microbial diversity and ecosystem restoration (Benyoucef et al., 2013; Cheikh et al., 2013; Avila et al., 2013; Tait et al, 2013).

\subsection{Start-up and acclimation of the UASB reactors with and without zeolite}

On the basis of results achieved in experimental run 1 it was decided that zeolite with a diameter of $1 \mathrm{~mm}$ should be used in the second experimental run, for which two UASB reactors were tested, one without zeolite and the other with added zeolite. This zeolite particle size is within the diameter range considered to be adequate when other reactor configurations were used (Milan et al., 2001 and 2003; Montalvo et al., 2005).

Figures 3 shows the variation of the COD content with time during acclimation stages 2 and 3. As can be seen during the second step almost no reduction of the COD content was observed. This behaviour can be explained by the inoculum not fully acclimating to the synthetic substrate and by the origin of the inoculum, which was adapted to remove only organic matter but not to substrates with high nitrate concentrations. By contrast, Figure 3 also shows how a rapid COD degradation took place in the third stage, especially after the first 7 days of the operating period, which shows how this stage led to the development of a heterotrophic biomass such as denitrifier bacteria. During this stage the influence of the added zeolite was observed at 
the end of the experimental run (lasting 5 days), with COD degradation higher than in the UASB reactor without zeolite. This can be attributed to the higher cell growth achieved in the reactor with zeolite, as can be seen in Figure 4 (a-d). Figure 4 (a and c) shows how the anaerobic sludge fills part of the internal wall of the reactor as well as the upper baffles in the UASB reactor with zeolite, while the reactor without zeolite shows low levels of biomass and a different light colour in its walls (Figure 4 (b-d)). It is worth mentioning that the UASB reactor with zeolite contained only $250 \mathrm{~g}$ of zeolite, which corresponds to only $2 \%$ of the total volume of the reactor. Moreover, and despite the high growth of biomass in this reactor, VSS in the process effluents (biomass losses) were not observed in any case.

Other digester configurations such as a hybrid anaerobic biofilm and sludge reactor (HABSR) were shown to be very effective in simultaneous methanogenesis and denitrification as was investigated in batch tests (Zhong et al., 2010). However, in this case as the nitrate concentration was increased from 75 to $600 \mathrm{mg} / \mathrm{L}$, COD removal rates were reduced from 95 to $1.7 \mathrm{mg} /(\mathrm{h} \cdot \mathrm{g})$.

Figure 5 shows the evolution of $\mathrm{pH}$ with time during the second stage of the startup process. An increase in $\mathrm{pH}$ values with time was observed in both cases due to the use of nitrate as the oxidant agent and the formation of hydroxide ion according to equation (2). In the same way, a considerable increase in $\mathrm{pH}$ and alkalinity was also observed during the biological denitrification of anaerobic effluents carried out in batch reactors at a temperature of $22^{\circ} \mathrm{C}$ with volatile fatty acid (VFA) concentration in the range of 20-200 mg/L (Elefsiniotis et al., 2004). 
The variation of effluent nitrate concentration with time during the second stage of the start-up period is shown in Figure 6. As can be seen, during the first 4 days the nitrate concentration decreased by only $6.7 \%$ of its initial value despite the fact that a denitrifier population is apparently found in the reactors to remove the nitrate at higher rates. However, the nitrate was totally removed on the $7^{\text {th }}$ day in the reactor with zeolite, while it was not completely consumed until the $11^{\text {th }}$ day in the reactor without zeolite, which fits with the more accentuated growth of the dentrificant biomass in the reactor with zeolite.

Denitrification processes of landfill leachates in fixed bed reactors were simulated at laboratory scale using anaerobic batch tests and columns packed with immature compost and pine bark (Trois et al. 2010b). Leachates with nitrate concentrations of 350, 700 and $1100 \mathrm{mg} \mathrm{N} / \mathrm{L}$ were used for these trials. These nitrate concentrations were lower than those used in the present study. Preliminary results suggested that after the acclimatization step (40 days for both substrates), full denitrification is achieved in 1020 days for the pine bark and 30-40 days for the compost (Trois et al. 2010b).

Figure 6 also illustrates the variation of the ammonium concentration with time during the second stage of the acclimatization period. A marked decrease in ammonium concentration from the first days of the start-up period was observed, the reactor with zeolite showing the lowest values. This behaviour can be attributed to the cationic exchange and adsorption capacities of the zeolite and its selectivity by this compound. This hypothesis can be corroborated through different ammonium adsorption experiments using the same zeolite as used in the UASB reactor (Mery et al., 2012). These experiments revealed that natural zeolite $1 \mathrm{~mm}$ in diameter adsorbed the 
ammonium ion following a Langmuir isotherm according to this expression: $Q e=$ $0.00033 \cdot C e^{1 / 0.56}$, where $Q e$ is the mass of substance adsorbed per unit of mass of zeolite in the equilibrium ( $\mathrm{mg} \mathrm{NH}{ }_{4}^{+} / \mathrm{g}$ zeolite), $\mathrm{Ce}$ is the concentration of substance in the liquid in the equilibrium ( $\mathrm{mg} \mathrm{NH}_{4}^{+} / \mathrm{L}$ ) (Mery et al., 2012). In addition, ammonium consumption by the microorganisms and its incorporation into their cell tissues also contributes to ammonium removal.

The simultaneous removal of carbon and nitrogen of the anaerobically pretreated distillery wastewater with nitrate, nitrite and added ammonium was studied in an expanded granular sludge bed (EGSB) reactor inoculated with methanogenic granular sludge (Li et al., 2011). At high $\mathrm{C} / \mathrm{N}$ ratios of 10 and 8, little total Kjeldahl nitrogen (TKN) was removed. However, $30 \%-50 \%$ of TKN entering the reactor was removed at lower $\mathrm{C} / \mathrm{N}$ ratios of 2, 3 and 4 suggesting the removal of ammonium (Li et al., 2011), in a similar way to what occurs in the present study.

\subsection{Operation of the UASB reactors in continuous mode at pseudo-steady state}

Once the acclimatization and start-up stages of the UASB were completed, both reactors operated in continuous mode at an organic loading rate of $44 \mathrm{~kg} \mathrm{COD} /\left(\mathrm{m}^{3} \cdot\right.$ day $)$ and a hydraulic retention time of 2.5 hours for an operating period of 60 days. During this period the reactors operated with an upward velocity of $0.44 \mathrm{~m} / \mathrm{h}$, which is somewhat lower than that used in a conventional UASB $(0.5-1 \mathrm{~m} / \mathrm{h})$.

Figure 7 shows the evolution of influent and effluent nitrate concentrations with time for the reactors with and without zeolite. Lower nitrate concentrations were always 
observed in the reactor with zeolite, which led to nitrate concentrations as low as $17 \mathrm{mg}$ $\mathrm{NO}_{3}{ }^{-} / \mathrm{L}$.

With the aim of observing the robustness of the process against the variation of nitrate loads, the process performance was assessed for nitrate loads ranging between 4.18 and $7.52 \mathrm{~kg} \mathrm{NO}_{3}{ }^{-} \mathrm{N} /\left(\mathrm{m}^{3} \cdot \mathrm{d}\right)$. Under these conditions, nitrate removal efficiencies in the ranges of $43.5 \%-97.0 \%$ and $20.6 \%-54.5 \%$ were achieved for the reactors with and without zeolite, respectively. As can be observed in Figure 7, from day 43 onwards the influent nitrate concentration was kept constant, which was equivalent to a nitrate load of $6.42 \mathrm{~kg} \mathrm{NO}_{3}^{-}-\mathrm{N} /\left(\mathrm{m}^{3} \cdot \mathrm{d}\right)$, achieving nitrate removal efficiencies of $61.2 \%$ and $92.4 \%$ for the reactors without and with zeolite, respectively. The high nitrate removal efficiencies found in the UASB reactor with zeolite under continuous feeding can be explained by the lower mass transfer limitation for denitrifiers presumably located in the outer layer of biomass aggregates supported on zeolite (Kalyuzhni et al., 2007).

Figure 8 shows the variation of the $\mathrm{pH}$ with time in the reactors with and without zeolite, as well as the influent $\mathrm{pH}$ evolution. As can be seen, the effluent $\mathrm{pH}$ achieved slightly alkaline values ranging between 7.19 and 8.34 without detecting process inhibition. It could be observed that the $\mathrm{pH}$ values in the reactor with zeolite were always slightly higher than those obtained in the reactor without zeolite. In addition, the average COD removal efficiencies in the reactors with and without zeolite were $30 \%$ and $24 \%$, respectively, during the operation period in continuous mode.

\section{CONCLUSIONS}


Laboratory-scale denitrificant reactors operating in batch mode with added zeolite showed high microbial diversity with the strong presence of Gammaproteobacteria. Archaea were only observed in the reactors with zeolite $1 \mathrm{~mm}$ in diameter. Bacteria belonging to the Gammaproteobacteria class were the best adapted to the denitrification conditions studied.

An experimental procedure or protocol following three stages was implemented for the start-up of UASB reactor with natural zeolite. This procedure and the adequate acclimatization of the inoculum led to higher nitrate removal efficiencies in this reactor than for the UASB without zeolite. A higher biomass growth was always observed in the reactor with zeolite.

The robustness of the reactor with zeolite achieving high nitrate removal efficiencies when operating under important variations of nitrate loads was shown. To be specific, nitrate removals higher than $92 \%$ were achieved when the reactor operated in continuous mode at high organic loading rates $\left(44 \mathrm{~kg} \mathrm{COD} /\left(\mathrm{m}^{3} \cdot \mathrm{d}\right)\right)$ and low hydraulic retention times $(2.5 \mathrm{~h})$.

\section{ACKNOWLEDGEMENTS}

The authors wish to express their gratitude to Fondecyt Project No.1090414 (Chile) for its financial support.

\section{REFERENCES}


Abe, D.S., Matsamura-Tundisi, T., Rocha, O., Tundisi, J.G., 2003. Denitrification and bacterial community structure in the cascade of six reservoirs of a tropical river in Brazil. Hidrobiologia 504, 67-76.

Amann, R.I., Binder, B.G., Olson, R.J., Chisholm, S.W., Devereux, R., Stahl, D.A., 1990. Combination $16 \mathrm{~S}$ rRNA-targeted oligonucleotide probes with flow cytometry for analyzing mixed microbial populations. Appl. Environ. Microbiol. $56,1919-1925$.

American Public Health Association (APHA), 1998. Standard Methods for the Examination of Water and Wastewater, 20th ed.; American Public Health Association/American Water Works Association/Water Environment Federation, Washington DC, USA.

Andalib, M., Nakhla, G., McIntee, E., Zhu, J., 2011. Simultaneous denitrification and methanogenesis (SDM): Review of two methanogenesis decades of research. Desalination 279, 1-14.

Andalib, M., Nakhla, G., Zhu, J., 2012. High-rate biological nutrient removal from high-strength wastewater using anaerobic-circulating fluidized bed bioreactor (ACFBBR). Bioresour. Technol. 118, 526-535.

Avila, C., Garfi, M., Garcia, J., 2013. Three-stage hybrid constructed wetland system for wastewater treatment and reuse in water climate regions. Ecol. Eng. 61, 43-49.

Basu, D., Gupta, S.K., 2010. Biodegradation of 1,1,2,2-tetrachloroethane in Upflow Anaerobic Sludge Blanket (UASB) reactor. Bioresour. Technol. 101, 21-25.

Benyoucef, N., Cheikh, A., Drouiche, N., Lounici, H., Mameri, N., Abdi, N., 2013. Denitrification of groundwater using Brewer's spent grain as biofilter media. Ecol. Eng. 52, 70-74. 
Bravo, R., Segovia, E., Guerrero, L., Montalvo, S., Barahona, A., Borja, R., 2013. Total amoniacal nitrogen biofiltration of wastewaters from aquaculture systems using Macrocystis spp. J. Environ. Sci. Health A 48, 400-407.

Cheikh, A., Yala, A., Drouiche, N., Abdi, N., Lounici, H., Mameri, N., 2013. Denitrification of water in packed beds using bacterial biomass immobilized on waste plastics as supports. Ecol. Eng. 53, 329-334.

Cheneby, D., Philippot, L., Hartmann, A., Henault, C., Germon, J.C., 2000. 16R DNA analysis for characterization of denitrifying bacteria isolated from tree agricultural soils. FEEMs Microbiol. Ecol., 34, 121-128.

Chong, S., Sen, T.K., Kayaalp, A., Ang, H.M., 2012. The performance enhancements of upflow anaerobic sludge blanket (UASB) reactors for domestic sludge treatment. A state-of-the-art-review. Water Res. 46, 3434-3470.

Elefsiniotis, P., Wareham, D.G., Smith, M.O., 2004. Use of volatile fatty acids from an acid-phase digester for denitrification. J. Biotechnol. 114, 289-297.

Fernández, N., Montalvo, S., Fernández-Polanco, F., Guerrero, L., Cortés, I., Borja, R., Sánchez, E., Travieso, L., 2007. Real evidences about zeolite as microorganisms immobilizer in anaerobic fluidized bed. Process Biochem. 42, 721-728.

Grabowski, A., Nercessian, O., Fayolle, F., Blanchet, D., Jeanthon, C., 2005. Microbial diversity in production waters of a low-temperature biodegraded oil reservoir. FEMS Microbiol. Ecol. 54, 427-433.

Huiliñir, C., Aspé, E., Roeckel, M., 2011. Modeling of the denitrification/anaerobic digestion process of salmon fishery wastewater in a biofilm tubular reactor. J. Environ. Manage. 92, 1591-1608. 
Hulshoff Pol, L.W., de Castro, S.I., Lettinga, G., Lens, P.N.L., 2004. Anaerobic sludge granulation. Water Res. 38, 1376-1389.

Jiang, T., Zhang, H., Qiang, H., Yang, F., Xu, X., Du, H., 2013. Start-up of the anammox process and membrane fouling analysis in a novel rotating membrane bioreactor. Desalination 311, 46-53.

Kalyuzhnyi, S., Gladchenko, M., Mulder, A., Versprille, B., 2007. Comparison of quasisteady-state performance of the DEAMOX process under intermittent and continuous feeding and different nitrogen loading rates. Biotechnol. J. 2, 894-900.

Li, J., Zhang, Z., Liu, Q., Yang, Q., 2011. The simultaneous removal of carbon and nitrogen from the anaerobically pretreated distillery wastewater in an anaerobic expanded granule sludge bed (EGSB) reactor. Appl. Mech. Mater. 90-93, 29392943.

Lu, X., Zhang, T., Han-Ping Fang, H., Leung, K.M.Y., Zhang, G., 2011. Biodegradation of naphthalene by enriched marine denitrifying bacteria. Int. Biodeterior. Biodegrad. 65, 204-211.

Malekian, R., Abedi-Koupai, J., Eslamian, S.S., Mousavi, S.F., Abbaspour, K.C., Afyuni, M., 2011. Ion-exchange process for ammonium removal and release using natural Iranian zeolite. Appl. Clay Sci. 51, 323-329.

Mery, C., Guerrero, L., Alonso-Gutiérrez, J., Figueroa, M., Lema, J.M., Montalvo, S., Borja, R., 2012. Evaluation of natural zeolite as microorganism support medium in nitrifying batch reactors: Influence of zeolite particle size. J. Environ. Sci. Health A 47, 420-427. 
Milán, Z., Sánchez, E., Weiland, P., Borja, R., Martín, A., Ilangovan, K., 2001. Influence of different natural zeolite concentrations on the anaerobic digestion of piggery waste. Bioresour. Technol. 80, 37-43.

Milán, Z., Villa, P., Sánchez, E., Montalvo, S., Borja, R., Ilangovan, K., Briones, R., 2003. Effect of natural and modified zeolite addition on anaerobic digestion of piggery wastes. Water Sci. Technol. 48, 263-269.

Mills, H.J., Hunter, E., Mumphrys, M., Kerkhof, Mc., Huettel, M., Kostka, J.E., 2008. Characterization of nitrifying, denitrifying and overall bacterial communities in permeable marine sediments of Northeaster Gulf of Mexico. Appl. Environ. Microbiol. 74, 4440-4453.

Montalvo, S., Díaz, F., Guerrero, L., Sánchez, E., Borja, R., 2005. Effect of particle size and doses of zeolite addition on anaerobic digestion processes of synthetic and piggery wastes. Process Biochem. 40, 1475-1481.

Montalvo, S., Olivares, P., Guerrero, L., Borja, R., 2011. Nitrogen and phosphorus removal using a novel integrated system of natural zeolite and lime. J. Environ. Sci. Health A 47, 1385-1391.

Montalvo, S., Guerrero, L., Borja, R., Sánchez, E., Milán, Z., Cortés, I., de la Rubia, M.A., 2012. Application of natural zeolites in anaerobic digestion processes: A review. Appl. Clay Sci. 58, 125-133.

Morita, M., Uemoto, H., Watanabe, A., 2008. Nitrogen-removal bioreactor capable of simultaneous nitrification and denitrification for application to industrial wastewater treatment. Biochem. Eng. J. 41, 59-66. 
Puyol, D., Mohedano, A.F., Sanz, J.L., Rodríguez, J.J., 2009. Comparison of UASB and EGSB performance on the anaerobic biodegradation of 2,4-dichlorophenol. Chemosphere 76, 1192-1198.

Rezakazemi, M., Shirazian, S., Ashrafizadeh, S.N., 2012. Simulation of ammonia removal from industrial wastewater streams by means of a hollow-fiber membrane contactor. Desalination 285, 383-392.

Rincon, B., Borja, R., Gonzalez, J.M., Portillo, M.C., Saiz-Jimenez, C., 2008. Influence of organic loading rate and hydraulic retention time on the performance, stability and microbial communities of one-stage anaerobic digestion of two-phase olive mill solid residue. Biochem. Eng. J. 40, 253-261.

Rodríguez, D.C., Pino, N., Peñuela, G., 2011. Monitoring the removal of nitrogen by applying a nitrification.denitrification porcess in a Sequencing Batch Reactor (SBR). Bioresour. Technol. 102, 2316-2321.

Shen, Z., Zhou, Y., Wang, J., 2013. Comparison of denitrification performance and microbial diversity using starch/polylactic acid blends and ethanol as electron donor for nitrate removal. Bioresour. Technol. 131, 33-39.

Tait, D.R., Erler, D.V., Dakers, A., Davison, L., Eyre, B.D., 2013. Nutrient processing in a novel on-site wastewater treatment system designed for permaeable carbonate sand environments. Ecol. Eng. 57, 413-421.

Trois, C., Coulon, F., de Combret, C.P., Martins, J.M.F., Oxarango, L., 2010a. Effect of pine bark and compost on the biological denitrification process of non-hazardous landfill leachate: Focus on the microbiology. J. Hazard. Mater. 181, 1163-1169. 
Trois, C., Pisano, G., Oxarango, L., 2010b. Alternative solutions for the biodenitrification of landfill leachates using pine bark and compost. J. Hazard. Mater. $178,1100-1105$.

Uysal, A., Yilmazel, Y.D., Demirer, G.N., 2010. The determination of fertilizer quality of the formed struvite from effluent of a sewage sludge anaerobic digester. J. Hazard. Mater. 181, 248-254.

Xiao, Y., Zeng, G.M., Yang, Z.H., Liu, Y.Sh., Ma, Y.H., Yang, L., Wang, R.J., Xu, Zh.Y., 2009. Coexistence of nitrifiers, denitrifiers and Anammox bacteria in a sequencing batch biofilm reactor as revealed by PCR-DGGE. J. Appl. Microbiol. $106,496-505$

Yetilmezsoy, K., Sapci-Zengin, Z., 2009. Recovery of ammonium nitrogen from the effluent of UASB treating poultry manure wastewater by MAP precipitation as a slow release fertilizer. J. Hazard. Mater. 166, 260-269.

Yu, R., Geng, J., Ren, H., Wang, Y., Xu, K., 2013. Struvite pyrolysate recycling combined with dry pyrolysis for ammonium removal from wastewater. Bioresour. Technol. 132, 154-159.

Zhang, T., Ding, L., Ren, H., Xiong, X., 2009. Ammonium nitrogen removal from coking wastewater by chemical precipitation recycle technology. Water Res. 43, $5209-5215$.

Zhong, C.Y., Ye, J.X., Li, R.Y., Chen, S., Sun, D.Z., 2010. Influence of nitrate on simultaneous methanogenesis and denitrification reaction of anaerobic biofilm and granular sludge. Huanjing Kexue/Environmental Science 33 (12), 4387-4392. 


\begin{tabular}{|c|c|c|}
\hline & Unit & Amount \\
\hline Culture medium* & $\mathrm{mL}$ & 210 \\
\hline Zeolite** & $\mathrm{g}$ & 20 \\
\hline Inoculum & $\mathrm{mL}$ & 20 \\
\hline Temperature & ${ }^{\circ} \mathrm{C}$ & 37 \\
\hline $\mathrm{pH}$ & - & 7 \\
\hline $\mathrm{C} / \mathrm{N}$ ratio & $\mathrm{g} / \mathrm{g}$ & 10.5 \\
\hline Operation time & days & 28 \\
\hline \multicolumn{3}{|c|}{$\begin{array}{l}\text { *The culture medium of the denitrificant reactors was: } 1.5 \mathrm{~g} / \mathrm{L} \text { of } \mathrm{CH}_{3} \mathrm{COOH} ; 0.08 \mathrm{~g} / \mathrm{L} \\
\text { of } \mathrm{MgSO}_{4} \cdot 7 \mathrm{H}_{2} \mathrm{O} ; 0.3 \mathrm{~g} / \mathrm{L} \text { of } \mathrm{NaCl} ; 0.2 \mathrm{~g} / \mathrm{L} \text { of yeast extract; } 1.56 \mathrm{~g} / \mathrm{L} \text { of } \mathrm{KNO}_{3} ; 5.0 \mathrm{~g} / \mathrm{L} \\
\text { of } \mathrm{K}_{2} \mathrm{HPO}_{4} ; 1.5 \mathrm{~g} / \mathrm{L} \text { of } \mathrm{KH}_{2} \mathrm{PO}_{4} \text { and } 1 \mathrm{ml} / \mathrm{L} \text { of saline solution. } \\
* * \text { For each culture medium, three zeolite diameters }(0.5,1.0 \text { and } 2.0 \mathrm{~mm}) \text { were used } \\
\text { separately. Triplicate reactors were used for all cases studied. }\end{array}$} \\
\hline
\end{tabular}


Table 2. Sequences, target organisms and percentage of formamide (\% FA) used.

\begin{tabular}{lcccc}
\hline Probe & Chromo* & Sequence $(\mathbf{5}, \rightarrow \mathbf{3}$ ') & $\begin{array}{c}\text { \% FA/ NaCl } \\
(\mathbf{m M})\end{array}$ & Target organisms \\
\hline GAM42a* & Cy3 & GCC TTC CCA CAT CGT TT & 35 & Gammaproteobacteria \\
GAOQ431 & Cy3 & TCC CCG CCT AAA GGG CTT & 35 & Candidatus "Competibacter phosphatis" \\
ARC915 & Cy3 & GTG CTC CCC CGC CAA TTCCT & 40 & Archaea \\
MX825 & Cy3 & TCG CAC CGT GGC CGA CAC CTA GC & 50 & Some methanosaetaceae \\
MS821 & Fluos & CGC CAT GCC TGA CAC CTA GCG AGC & & Methanosarcina \\
& & & 40 & Methanobacteriales (minus \\
MB1174 & Cy3 & TAC CGT CGT CCA CTC CTT CCT C & 45 & Methanothermus) \\
\hline
\end{tabular}

\footnotetext{
*Chromosphero
} 


\section{FIGURE CAPTIONS}

Figure 1. Images of FISH: Left image shows a sample of the denitrificant anaerobic reactor with zeolite $1 \mathrm{~mm}$ in diameter: Archaea (Cy3: red colour) put on all biomass (DAPI: blue colour). Right image: sample of the denitrificant reactor with zeolite 0.5 in $\mathrm{mm}$ diameter: Gammaproteobacteria (Cy3: red colour) put on all biomass (DAPI: blue colour). Bar indicates $10 \mu \mathrm{m}$.

Figure 2. Left side: denaturing gradient gel electrophoresis (DGGE) analysis showing the bands of the samples DNB 1 and DNB 3 with the different groups found. Right side: interest bands, access numbers and closest microorganisms phylogenetically found.

Figure 3. Variation of COD (mg/L) with time (days) during stages 2 and 3.

Figure 4. Photograph of the UASB with zeolite (Fig. 4a: lower part; Fig. 4c: entire reactor) and of the UASB without zeolite (Fig. 4b: lower part: Fig. 4d: entire reactor).

Figure 5. Variation of the $\mathrm{pH}$ with time (days) during stage 2 of the start-up period.

Figure 6. Variation of the nitrate and ammonium concentrations $(\mathrm{mg} / \mathrm{L})$ with time (days) during stage 2 of the start-up period.

Figure 7. Evolution of the nitrate concentration $(\mathrm{mg} / \mathrm{L})$ with time (days) during the operation of the reactors in continuous mode.

Figure 8. Evolution of the $\mathrm{pH}$ with time (days) during the operation of the reactors in continuous mode. 

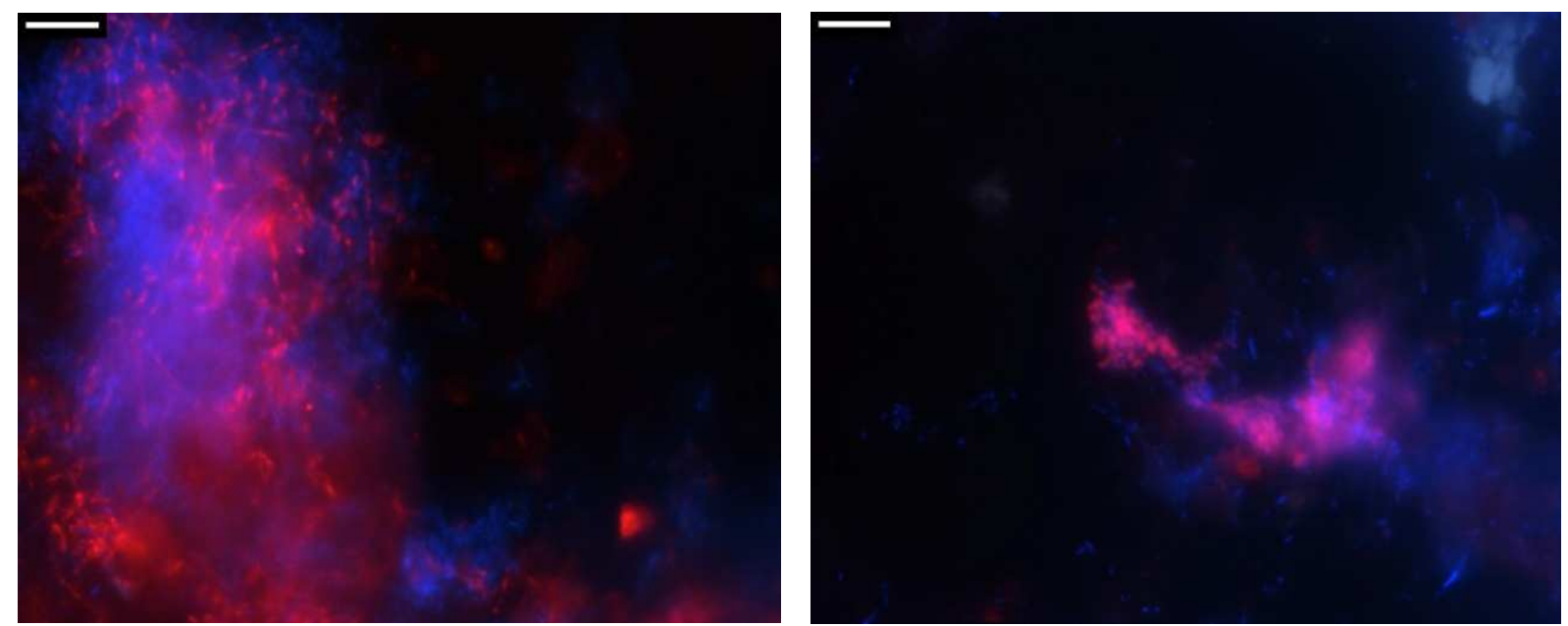

Figure 1 


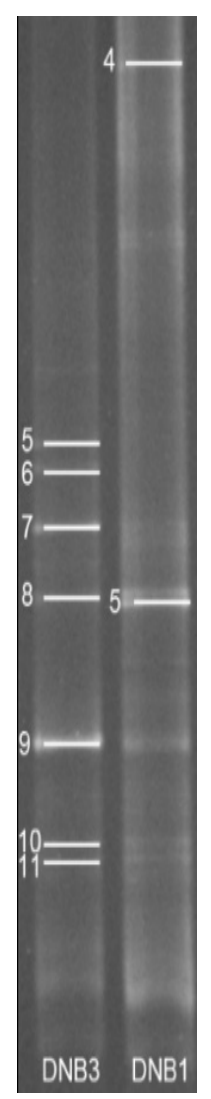

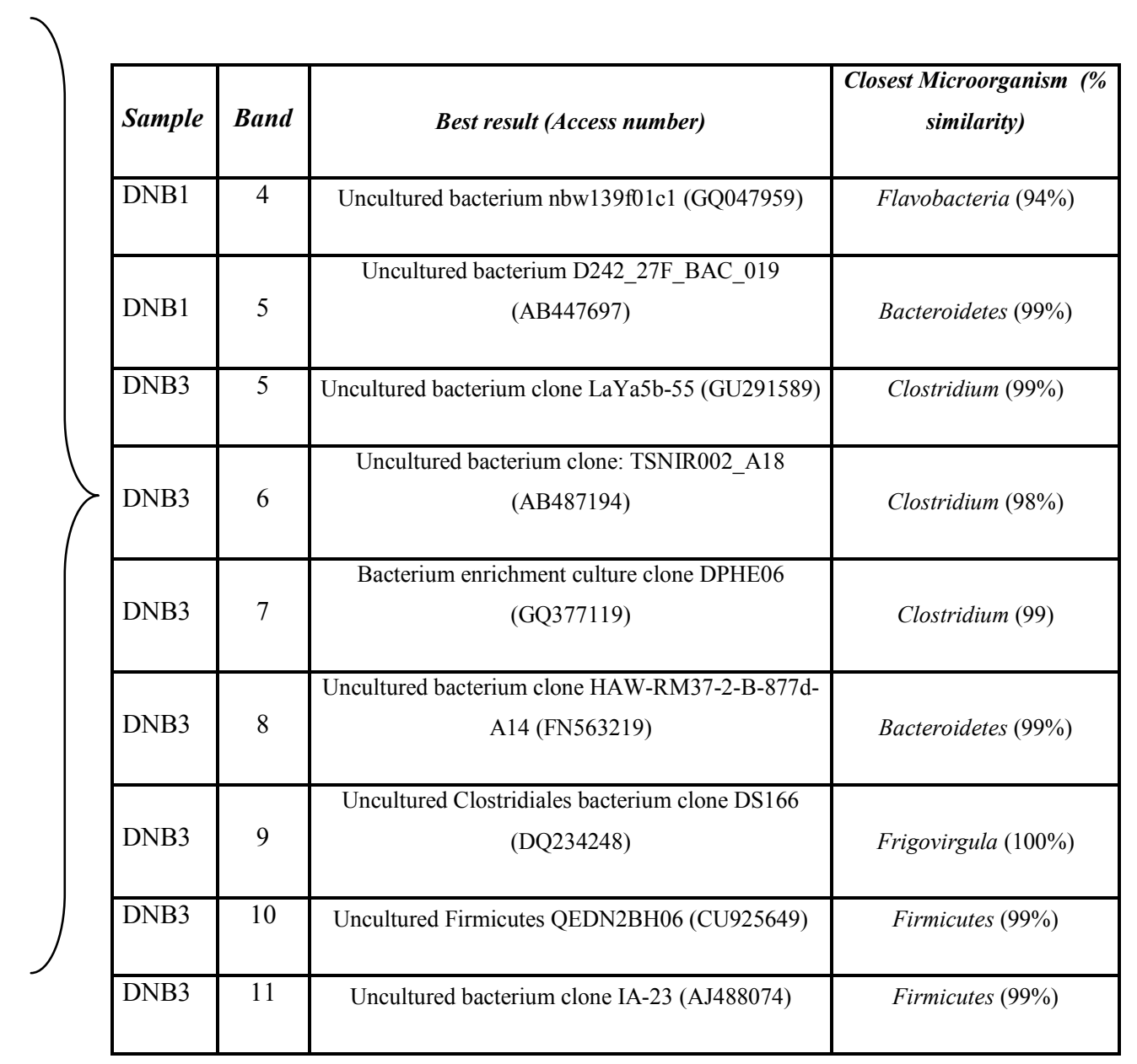

Figure 2. 


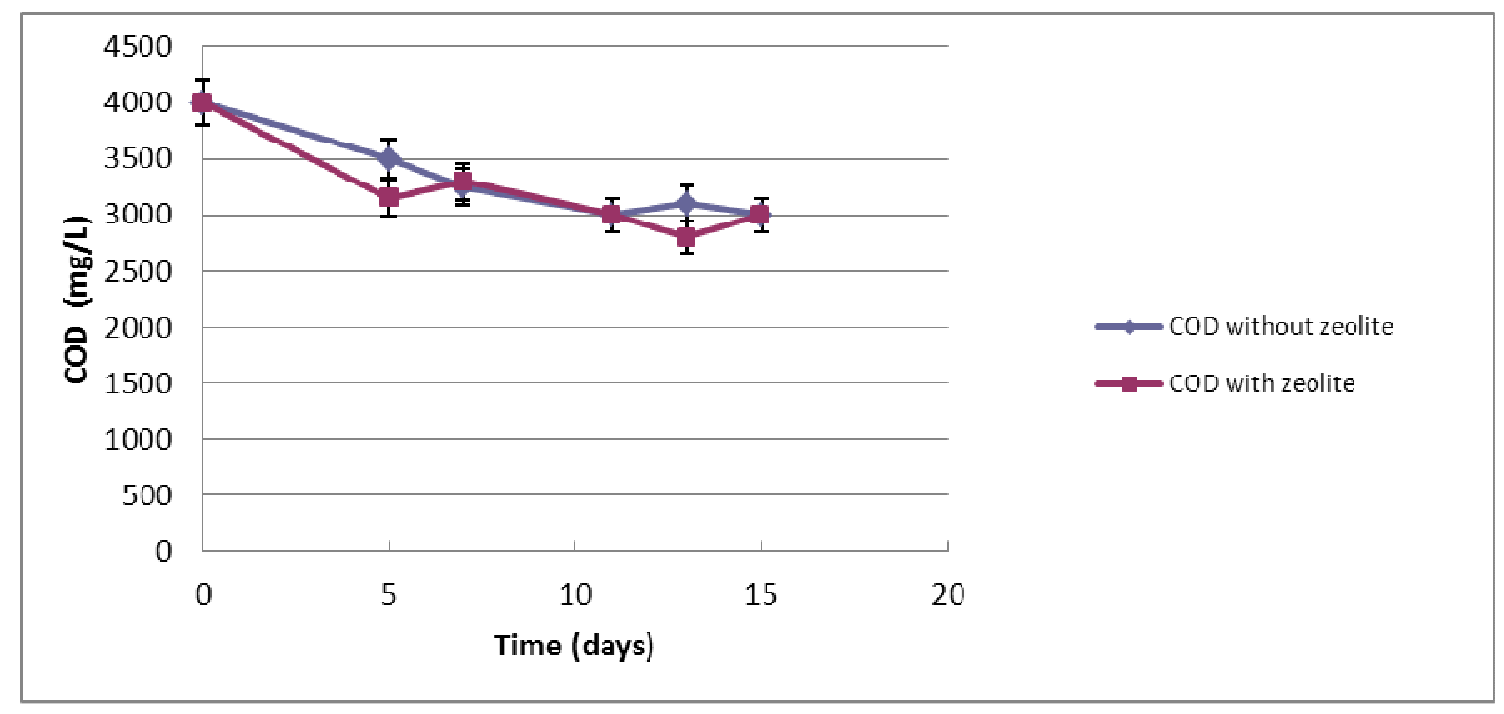

Fig. 3a

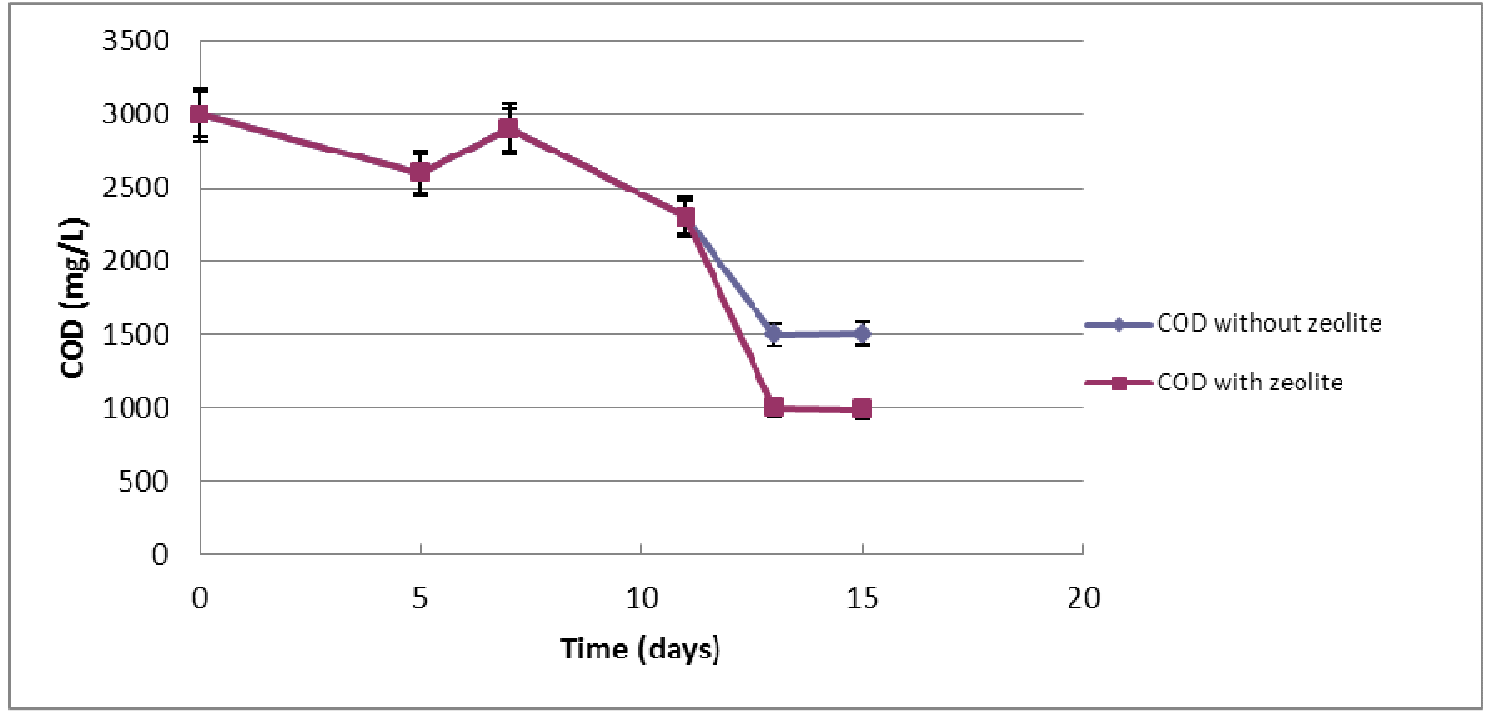

Fig. 3b 


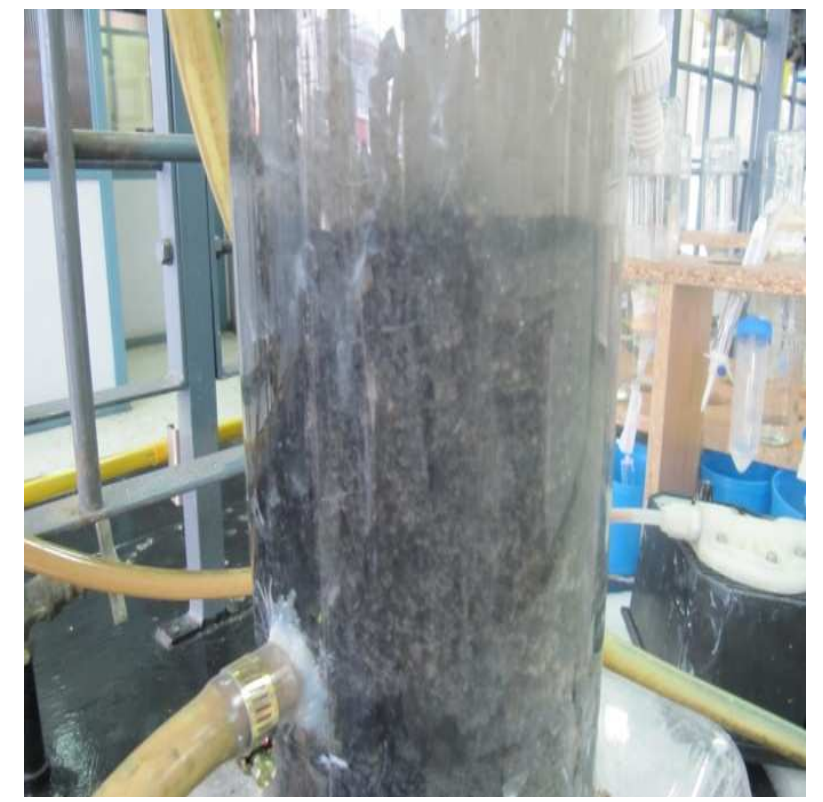

Fig. 4a

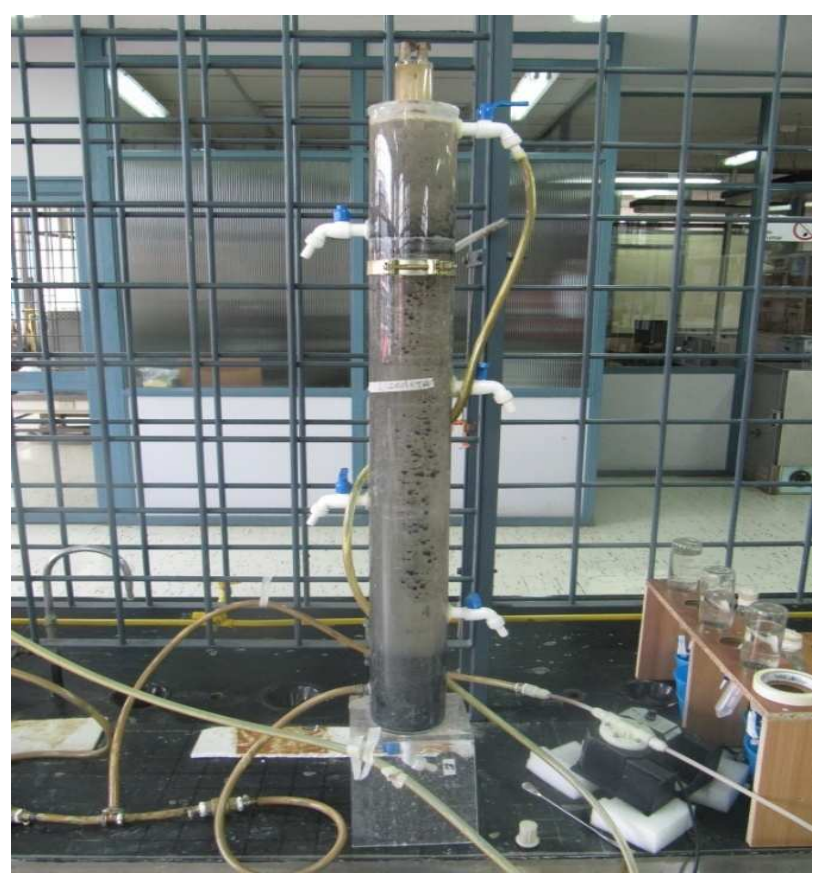

Fig. 4c

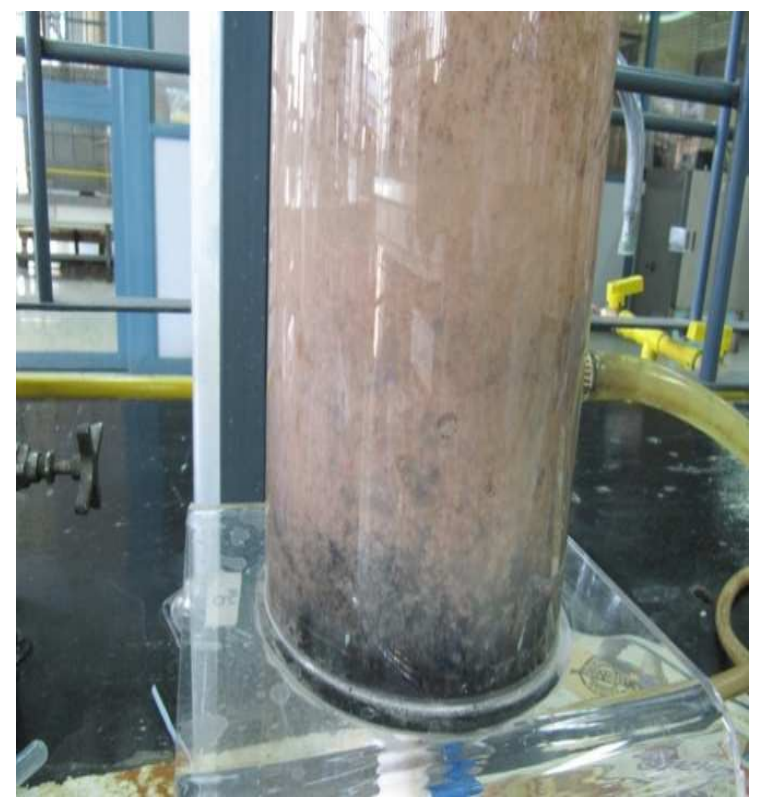

Fig. 4b

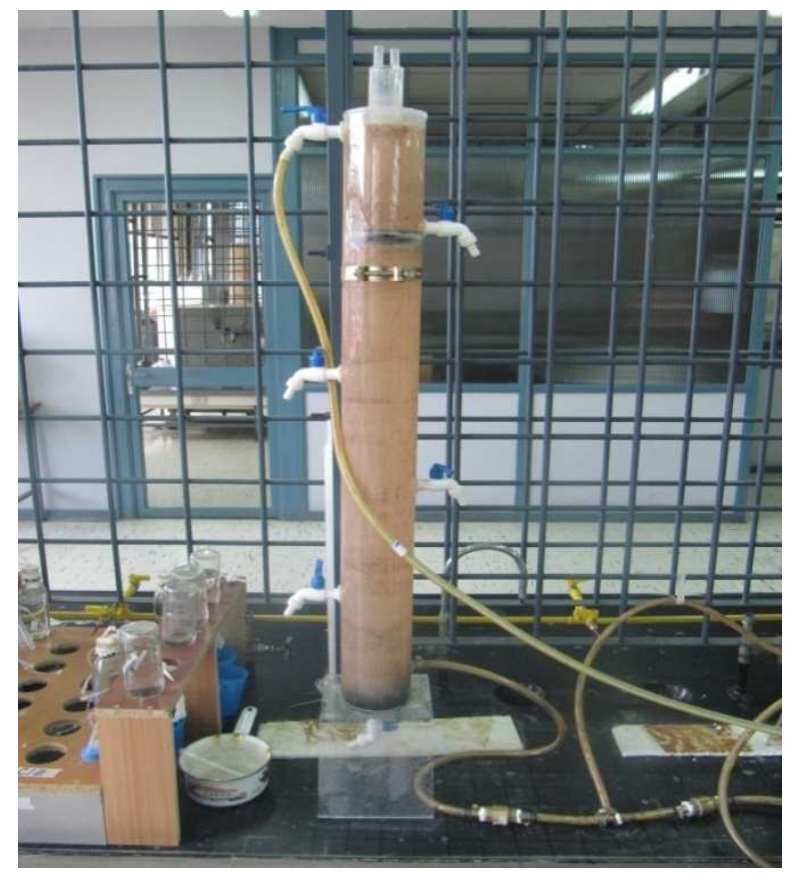

Fig. 4d 


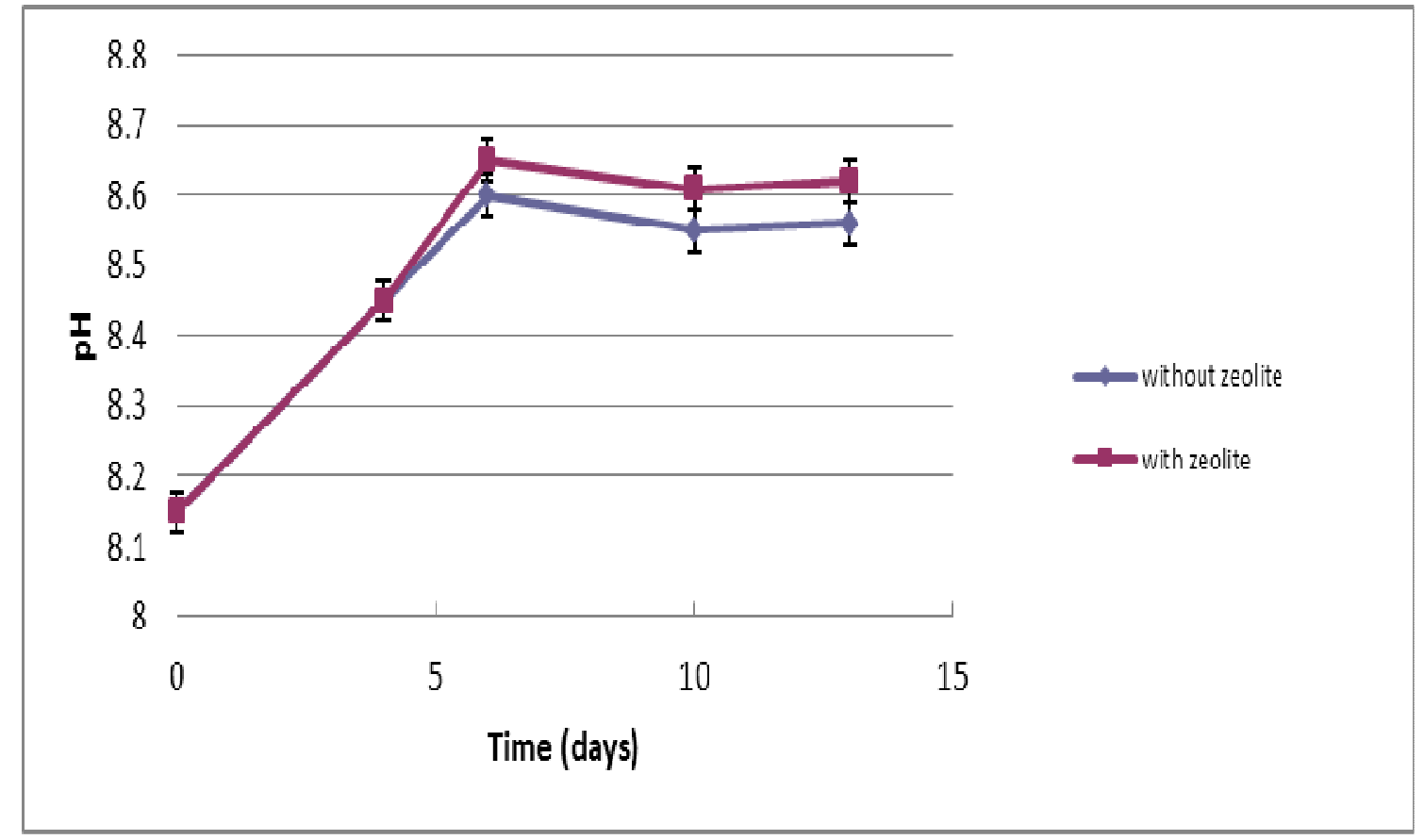

Figure 5 


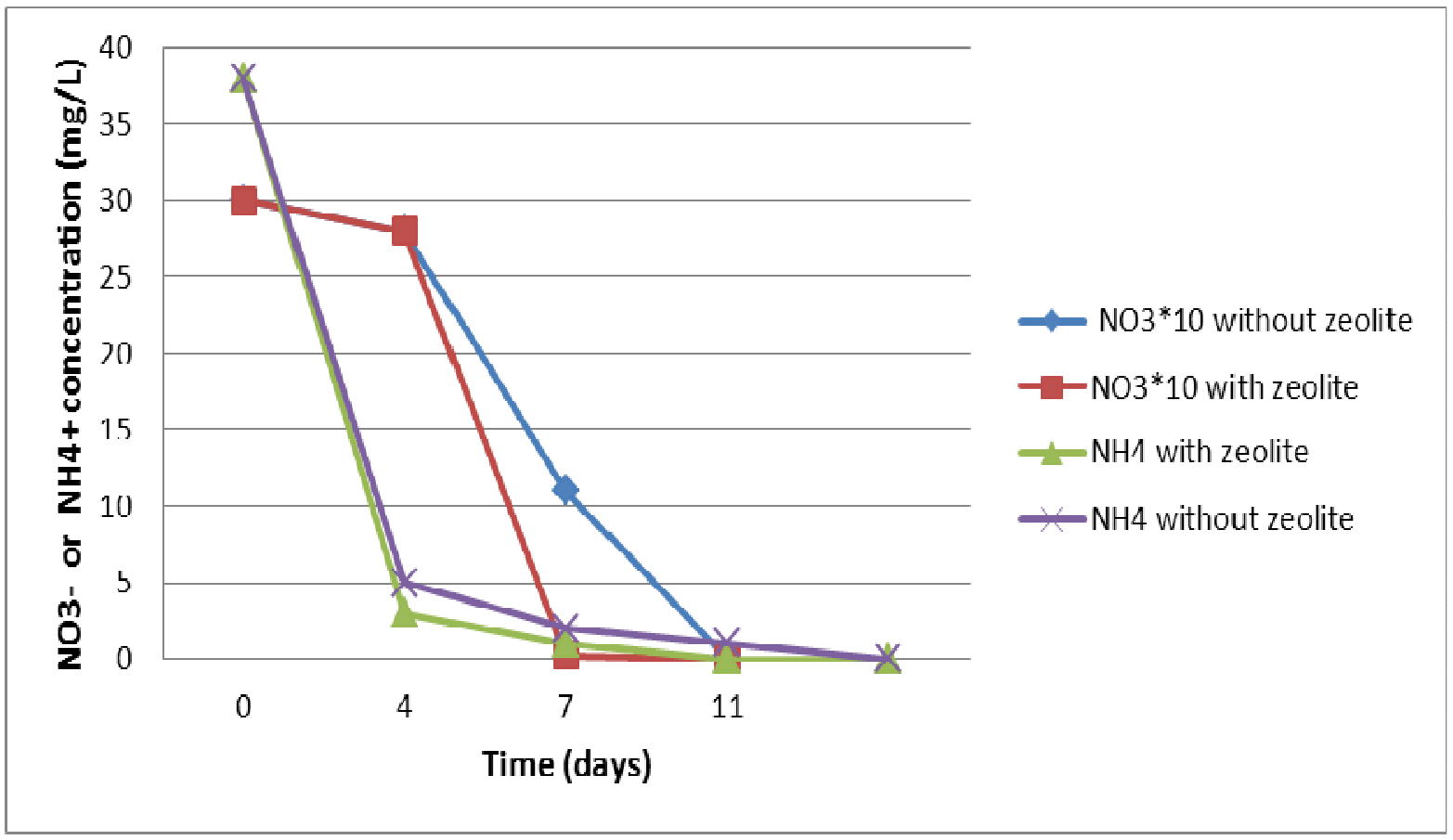

Figure 6 


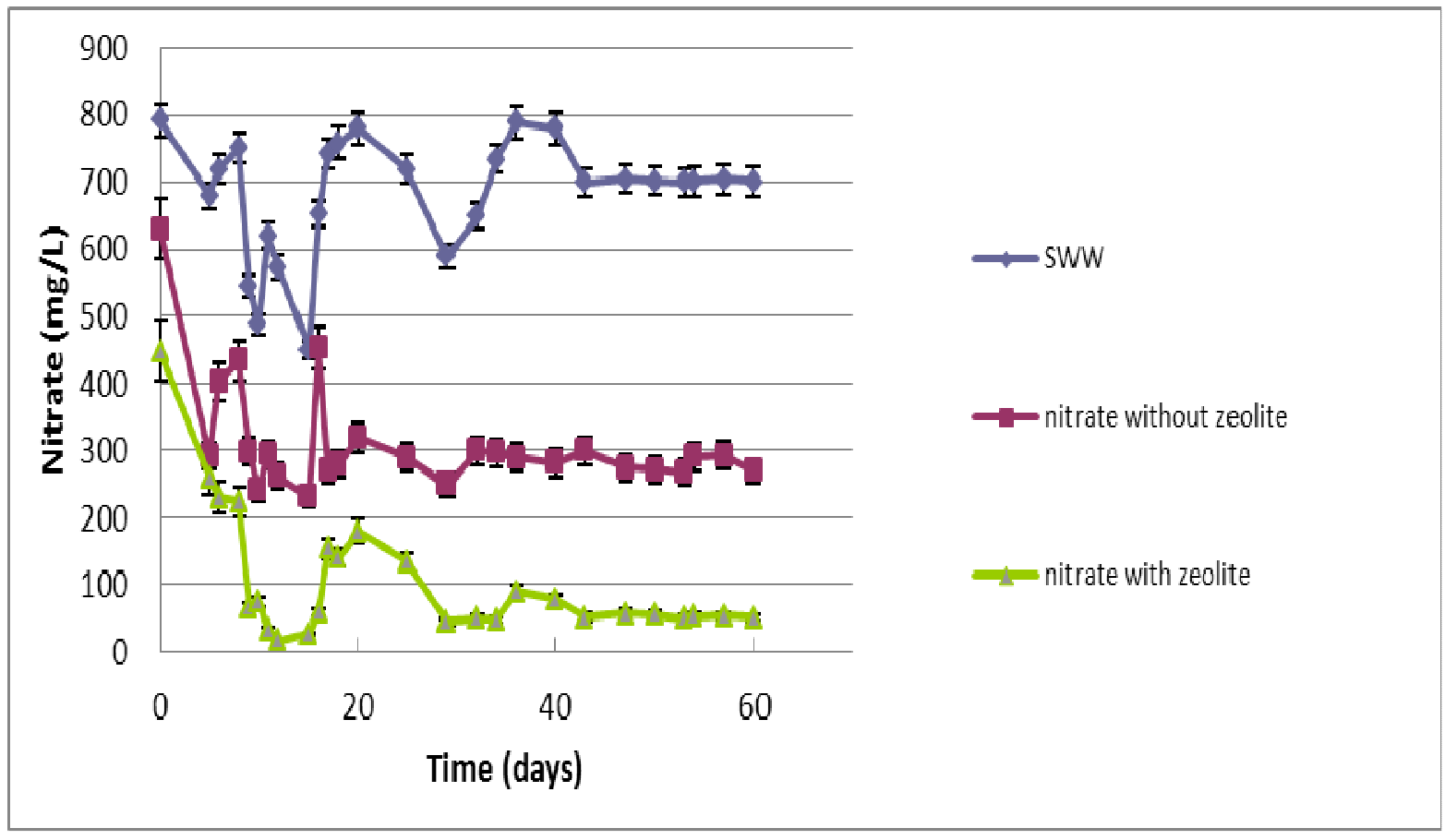

Figure 7 


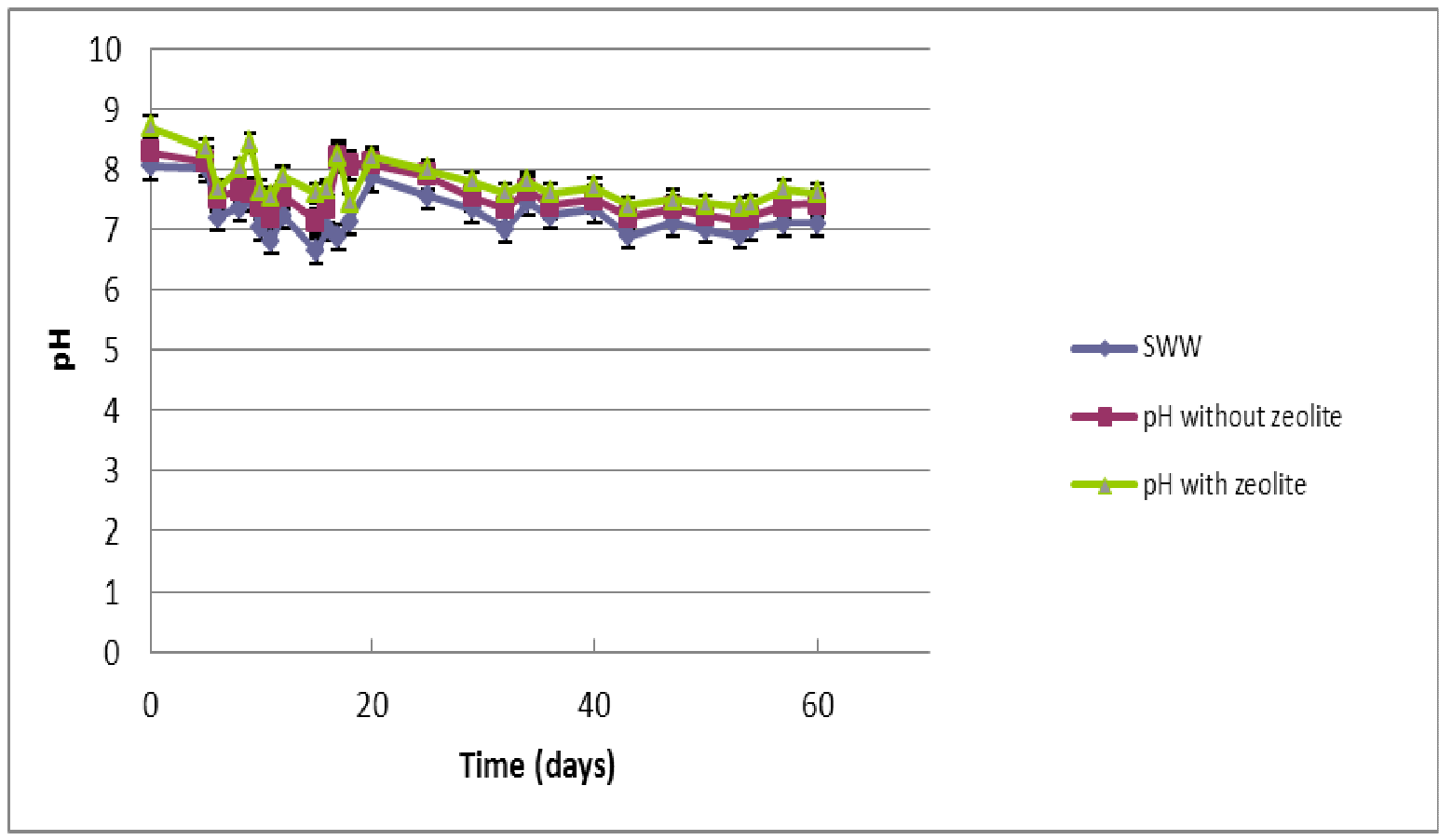

Figure 8 